\title{
Extraterritoriality from the Port: \\ EU's approach to jurisdiction over ship-source pollution
}

\author{
Nelson F. COELHO*
}

\begin{abstract}
Ship-source pollution represents a threat to the environment, regardless of where it occurs. The European Union has been developing standards that aim to counter accidental, operational and intentional pollution in the waters under its member-state's jurisdiction. However, and precisely because marine pollution knows no boundaries, the EU is not coy in contemplating what ships do beyond waters under the sovereignty of its member states. This article analyses the international lawfulness of EU claims to port state jurisdiction over ship-source pollution. It demonstrates that port state jurisdiction is today not only a means to ensure compliance with international standards but also a means to unilaterally enforce more stringent environmental standards.
\end{abstract}

Keywords: port state jurisdiction - extraterritoriality - EU environmental law - unilateralism - law of the sea

\section{INTRODUCTION}

Reports from port state control agents prove that not all ships respect international rules and standards on ship-source pollution. ${ }^{\mathrm{I}}$ It is also a fact that some states have, in isolation or as part of a regional effort, shown unequivocal intentions to bolster those international standards, namely by asserting national laws over ships that voluntarily call to or enter into their ports, i.e. through port state jurisdiction. ${ }^{2}$

As an international organization, the European Union [hereinafter EU] took that stand. In 2002 the European Commission proposed an accelerated schedule of implementation to the International Maritime Organization's [hereinafter IMO] calendar for the phasing out of single hull tankers.'It did so by relying on its member states' jurisdiction to regulate access to port, which provided international legality to an environmentally minded safety measure. More recently, in 2015, the EU has taken a very similar path with regards to ship-source air pollution. It was decided that from January 20I8, allshipping companies will have to monitor and report the verified amount of $\mathrm{CO}_{2}$ their large

* Doctoral Researcher in Public International Law at the Netherlands Institute for the Law of the Sea (NILOS), Utrecht University. The research which resulted in this publication has been funded by the Dutch Organization for Scientific Research under the VIDI Scheme. The author thanks his supervisor, prof. Cedric Ryngaert, and co-supervisor, dr. SelineTrevisanut for their comments on a draft version of this article. He also thanks his colleague, Arron N. Honniball, for reviewing the final draft. N.F.Coelho@uu.nl

See the current detentions at European ports in the European Maritime Safety Agency [EMSA] portal, available at $<$ https://portal.emsa.europa.eu/web/thetis/current-detentions >, accessed 25 August 2015.

B. Marten, Port State Jurisdiction And The Regulation Of Merchant Shipping (Springer, Heidelberg, 2015) at II7-160.

3 Regulation (EC) No 417/2002 of the European Parliament and of the Council of I8 February 2002 on the accelerated phasing-in of double hull or equivalent design requirements for single hull oil tankers and repealing Council Regulation (EC) No 2978/94. 
ships emit on voyages to, from, and between EU ports. ${ }^{4}$ Again, the EU has claimed jurisdiction because foreign ships entering a port and therefore the territory of one of its member states. Both these cases highlight a controverted element of the principles of international jurisdiction, namely the scope of territoriality under public international law and its legal relevance as a basis for port state prescriptions that consider extraterritorial conduct.

This paper looks at the concept and scope of port state jurisdiction. The question this paper aims to answer is: how does the EU make use, under international law, of port state jurisdiction to bolster bigher standards of protection for the marine environment? And, in particular which legislative techniques does it employ to do so? Answering this question will also require an inquiry into whether this kind of unilateral action poses or not a question of legality under public international law. ${ }^{5}$

The paper is structured in two main parts. The first part introduces what port state jurisdiction is, highlighting its two dimensions; as an international law enforcement mechanism, where the concept 'port state control' is of use, and as a distinct jurisdictional capacity that, by itself, may justify legislating over extraterritorial conduct. The second part analyses how the EU uses this second prerogative to achieve its objectives, in particular the protection of marine environment from pollution incidents. It offers some remarks on the international lawfulness of the legal techniques the EU has been using and which rely on its member's port state jurisdiction.

For the purpose of this article we refer to extraterritorial conduct as what occurs on the bigh seas. In other words, we analyse how the EU seeks to regulate conduct occurring beyond its member state's jurisdictional maritime zones through port state jurisdiction. This study does not discuss the application of EU law regarding ship conduct occurring in third States maritime zones nor the conduct occurring within a member state's maritime zones.

\section{THE TWO DIMENSIONS OF PORT STATE JURISDICTION}

The criminal jurisdiction of a state under international law is limited by certain principles. Custom demonstrates, and treaties confirm, that one fundamental attribute of sovereignty is the prima facie exclusive jurisdiction over a territory and the permanent population living therein. ${ }^{6}$ This means that the jurisdiction of a state is geographically limited to a fraction of the Earth's surface and that it cannot extend beyond the boundaries of that confined space, whether on land or at sea.

However, other factors exist that justify exceptions to this particular limit upon criminal jurisdiction under international law. A state can claim an "extraterritorial" jurisdiction based on the nationality of the persons involved in a certain conduct (the personality principle) or based on the protection of its internal order (the security principle). States are also entitled by international law to

\footnotetext{
4 Regulation (EU) 2015/757 of the European Parliament and of the Council of 29 April 2015 on the monitoring, reporting and verification of carbon dioxide emissions from maritime transport, and amending Directive 2009/16/EC.

5 Principle 12, Rio Declaration on Environment and Development, June 1992, 3I ILM (1992) 874.

6 P. Sands \& J. Peel, Principles of International Environmental Law (Cambridge University Press, Cambridge, 20I2) at
} II. 
act whenever a conduct constitutes a crime of international concern (the universality principle). ${ }^{7}$ These are the recognised principles of extraterritorial jurisdiction.

What is more, international treaties can, ad hoc, expand the exceptions to the territorial scope of a state's criminal jurisdiction. That is what happens, for example, in the 1982 Law of the Sea Convention [hereinafter UNCLOS], where entitlements of functional jurisdiction over maritime zones beyond the territory are provided inter alia to protect and preserve the marine environment. ${ }^{8}$

The fundamental premise of the following discussion is that when a ship enters the port, she is within the internal waters of a state and hence, within its territory. In the first half of this heading we discuss the capacity to assert laws at port. We firstly explain what port state control is and how it serves the purpose of enforcing the applicable international standards, i.e., those to which the port state has agreed to through a treaty, at the competent international organization, or in a general diplomatic conference (I). Secondly, we explain how port state jurisdiction under international law allows for the unilateral assertion of more stringent standards (2).

\section{(I) Application of International law via port state control}

This first heading aims at explaining how port state control serves to give application to international legal standards, namely those defined at the multilateral level.

International standards are agreed upon following multilateral negotiations, for example at the IMO Marine Environmental Protection Committee [hereinafter MEPC]. They consist mostly on amendments to the annexes of existing treaties; in some rare occasions, a new treaty with a new set of technical annexes is created. ${ }^{\text {But }}$ buen comes the issue of enforcement of such standards: how to ensure that ships worldwide comply with agreed technical standards? The answer to this question has traditionally been flag state jurisdiction, i.e., the state where the ship is registered assumes the responsibility to control the application of agreed environmental standards. ${ }^{\mathrm{o}}$ However, and due either to the resistance of some flag states in ratifying or to their material incapability in enforcing these treaties, a new approach based on the control at port constitutes today an efficient alternative and is increasingly referred to in international agreements. ${ }^{\text {II }}$

7 On principles of jurisdiction: C. Ryngaert, Jurisdiction In International Law (Oxford University Press, Oxford, 2015); I. Cameron The protective principle of international criminal jurisdiction (Aldershot, Dartmouth, 1994); L. Reydams, Universal jurisdiction: International and Municipal Legal Perspectives (Oxford University Press, Oxford, 2003).

8 United Nations Convention on the Law of the Sea, I833 UNTS 3; 2I ILM (1982) I26I. The term 'functional'is used by Benedetto Conforti to describe assertions of jurisdiction in the exclusive economic zone. Other authors, such as Maria Gavouneli, refer to it as 'functional jurisdiction'. M. Gavouneli, Functional Jurisdiction in the Law of the Sea (Martinus Nijhoff, Leiden, 2007); B. Conforti, International Law and the Role of Domestic Legal Systems (Martinus Nijhoff, Leiden, 1993). Some years before, another author also used this term: see W. Riphagen 'Some Reflections on Functional Sovereignty', Netherlands Yearbook of International Law (1974), at 227.

9 W. Van Reenen, 'Rules of Reference in the new Convention on the Law of the Sea, in particular in connection with the pollution of the sea by oil from tankers', I2 Netherlands Yearbook of International Law (I98I).

ro UNCLOS, supra n. 8, at Article 94 (flag state duties).

II E.J. Molenaar, 'Port State Jurisdiction: Toward Comprehensive, Mandatory and Global Coverage', 38 Ocean Development $\mathcal{G}$ International Law (2007) 225-257. 
Port state control provides a means to verify the compliance with those international rules and standards agreed at the multilateral level. ${ }^{12}$ Control agents ensure compliance of these rules and standards when the ship is at port. This control may consist on a system of administrative penalties ensuring that the ship does not leave port without addressing and solving the issues at stake. ${ }^{\mathrm{I}}$ Such issues may relate to multiple aspects of navigation: equipment, safety procedures, information on logbooks, carbon emissions, discharge, ballast waters, anti-fouling systems, etc.

Through the adoption of 'memoranda of understanding on port state control' [hereinafter MOU], states have sought to avoid losing competitive edges in their region that might result from enforcing multilateral standards in isolation. ${ }^{14}$ Today, these regimes are manifold and they create webs that virtually cover every main shipping port. Because we are talking of soft law agreements without any legally binding nature, ${ }^{15}$ some of these MOU, namely those inspired by the 1982 Paris MOU, consist primarily on a 'name and shame' strategy. Nonetheless, this regional approach seeks to ensure compliance with international standards by dissuading ships of being caught by port states while navigating under substandard conditions and of incurring in hefty fines. Because of their softness, MOU encourage port states to be responsible without imposing a burden that could discourage them from participating in regional and global agreements at all. ${ }^{16}$

Regardless of this role as an international standards' enforcement mechanism, control of international standards at port still has to rely on a sovereign asset: indeed, port state control can only exist because of port state sovereignty and hence of port state jurisdiction.

The capacity to act as a port state has a different legal scope than its related capacity to act as a coastal state. This occurs because a port state is not always a coastal state or simply not the coastal state directly affected, for example by a pollution incident. This may explain why states have been demonstrating in recent years that such a capacity can be used not only as a means of controlling whether ships abide to the applicable international standards but also as a legal ground to enact and enforce national laws imposing more stringent ones.

(2) Prescribing laws via port state jurisdiction

We now move to discuss port state jurisdiction in a different sense, referring to the prescription of national law rather than to the application of international standards.

12 G.C. Kasoulides, Port State Control and Jurisdiction, (MartinusNijhoff, Leiden, I993), at IIO-I4I.

3 UNCLOS, supra n. 8, at Article 218 (port state enforcement) on the particular case of discharge.

${ }^{14}$ D. König, 'Port State Control: An Assessment of European Practice', in P. Ehlers et al. (eds), Marine Issues: From a Scientific, Political and Legal Perspective (MartinusNijhoff, Leiden, 2002), at 37, explaining how the Amoco Cadiz incident motivated the development of the concept of regional port state control in the 1978 Hague Memorandum of Understanding on Port State Control. Also, T. McDorman, 'Regional port state control agreements: some issues of international law', 5 Ocean \& Coastal Law Journal (2000), at 207.

is D. Shelton, 'Soft Law', in D. Armstrong et al. (eds), Handbook of International Law (Routledge Press, London, 2008), at 68 .

16 The notion of a 'responsible port state', "a state committed to making the fullest possible use of its jurisdiction under international law in furtherance of not just its own rights and interests, but also those of the international community" is elaborated in E.J. Molenaar, supra n. II. 
The advantages of port-based regulation and enforcement of maritime standards has a number of advantages compared to coastal state regulation, which have already been concisely summarized:

"First of all, it is more practical to take enforcement measures against ships in port than at sea. It requires less time and resources for the port State authorities and involves fewer navigational impediments for the ships. Secondly, port State regulation at a regional level offers several advantages compared to national regulation. Through the harmonisation of requirements for ships entering ports in all the EU member states, a very significant proportion of the transiting ships may be covered, without having to resort to sea-based enforcement. Harmonisation of control and enforcement policies among a larger group of States also reduces the problem of 'ports of convenience', where more lenient standards apply. Thirdly, and most importantly for present purposes, regulation in the capacity of port State involves legal advantages, in the form of broader jurisdictional rights as regards prescription and enforcement, compared to the rights of coastal States." ${ }^{\text {17 }}$

In this heading we discuss the spatial scope of port state jurisdiction as to what concerns this third aspect: broader jurisdictional rights as regards prescription. We do not contest that the enforcement in itself is always based on the presence of the ship in the territory. However, port state prescriptive jurisdiction can either refer to (a) conduct that occurs within territory or (b) it can 'capture' conduct that occurs beyond such limits, i.e. extraterritorial conduct. The distinction between both is not always evident.

\section{(a) The territoriality of port state jurisdiction}

As we have referred, ports are located on the territory and are therefore considered, under international law, as being a part of it. Internal waters, where the ships actually remain when in port, are also part of the territory of the state. ${ }^{18}$ As such, everything that happens within the port falls under the port state's territorial jurisdiction.

Ships have, under international law, no right of access to a port, in the same way any person does not have a right to enter a foreign territory. ${ }^{19}$ A port can always close port access to ships or impose entry conditions. This closure follows certain procedural rules, such as a non-discrimination principle and due publicity of the conditions required to gain access to port. However, flag states still enjoy jurisdiction regarding the internal economy of the ship even when the ship is at port. ${ }^{20}$ This means that the ship is not under exclusive jurisdiction of the port state because of its presence in its territory but in a tense string of concurrent (and often competing) competences between the respective flag state and the port state.

The territoriality principle has not been designed as a basis for jurisdiction that captures conduct that occurred beyond the territorial sea but rather as a principle to grant jurisdiction over areas considered part of the territory. Nonetheless, some states still attempt to rely on the territorial

${ }_{17}$ H. Ringbom, The EU Maritime Safety Policy and International Law, (Martinus Nijhoff, Leiden, 2008), at 203.

I8 Z. Oya Özçayir, Port State Control (LLP, London, 200I), at 68 explaining that "[i]nternal waters consist of ports, harbours, lakes, rivers, canals and waters on the landward side of the baselines from which the breadth of the territorial sea is measured".

19 L. de La Fayette, 'Access to Ports in International Law', in International Journal of Marine e Coastal Law, (1996), pp. I-22.

20 Some authors would even call that a monopoly of jurisdiction. R.R. Churchill, \& V.A. Lowe, The Law of the Sea (Manchester University Press, Manchester, 1999) at 65-68 and 92-93. Against: B. Marten, supra n. 2, at 28. 
components of the conduct, namely the presence of the ship in port, to assert what would otherwise be considered an exercise of extraterritorial legislative jurisdiction. That is why we refer to extraterritoriality in the following heading.

\section{(b) The extraterritoriality of port state jurisdiction}

Extraterritoriality is not a concept over the meaning of which unanimity exists under international law. Even the phrase 'extraterritorial jurisdiction' is very rarely used in the doctrine of the law of the sea. ${ }^{2 \mathrm{I}}$ Before (ab)using it, we need to explain what it means.

Extraterritorial jurisdiction has been defined by the International Legal Commission [ILC] as "an attempt to regulate by means of national legislation, adjudication or enforcement the conduct of persons, property or acts beyond its borders which affect the interests of the State in the absence of such regulation under international law". ${ }^{22}$ Although originating from a highly respectable source, the accurateness of this definition must be assessed critically.

If we pay attention to what is stated in fine, we read: "affect the interests of the state", and also: "in the absence of regulation". What the ILC means with these two phrases is less than clear and, we would submit, inaccurate.

Point one: this conceptual delimitation fails to take into consideration that there are interests that are common to the international community as a whole. These interests establish a link to any state in the world that could then act on behalf of the community and under a substantially different jurisdictional ground. The usage of 'the state' instead of 'a state' in this definition does seem to implicitly assume a special link between the state that can lawfully assert extraterritorial jurisdiction and the conduct. In times where international law also serves purposes of global governance in the lack of a centralized authority, such a narrow approach might limit unilateral action and leave global values unprotected. ${ }^{23}$ Conflicts of jurisdiction would then motivate a blame game instead of a valueoriented distribution of competences and responsibilities.

Point two: reference to 'absence of regulation' assumes that extraterritorial jurisdiction is necessarily unilateral, which is not always the case. An exercise of jurisdiction based on a treaty or in any of the customary principles of extraterritorial jurisdiction can also be qualified by the exception they constitute to the territoriality principle. This means that all exceptions to the territorial limit to state jurisdiction are indeed exercises of extraterritorial jurisdiction. What is more, restricting extraterritorial jurisdiction to absence of regulation prevents states from acting when cooperation led to bad or insufficient regulation. Although international law encourages cooperation, nothing prevents a state from acting on its own, either before negotiations have started or after standards have been defined, provided the parties did not explicitly agreed so.

${ }_{21}^{21}$ J.E.S. Fawcett, 'General Course on Public International Law', I32 Hague Academy Collected Courses (1971), at 467, explains the term 'relational jurisdiction' as describing jurisdiction "which arises from a special relation between the object or area of jurisdiction and the state agent entitled to exercise it, the relation being sometimes called a link", one of such links being termed as 'common duty and interest'.

${ }_{22}$ United Nations Report of the International Law Commission, Fifty-eighth session (I May-9 June and 3 July-II August 2006) General Assembly Official Records, Supplement No. Io (A/6I/IO), at 5i6.

23 C. Ryngaert, Unilateral Jurisdiction and Global Values (Eleven Publishing, Den Haag, 2015) at 29. 
This definition fails to provide the needed clarity on what extraterritorial jurisdiction means in public international law. ${ }^{24}$ Another even greater challenge exists when we attempt to combine this definition with the articulation of jurisdictional capacities established by the law of the sea regime. It is so because a ship is not considered a floating part of a foreign territory. ${ }^{25}$ It is a registered vehicle that has a 'nationality' and is under the jurisdiction of a flag state. ${ }^{26}$ This is the case of the balance established between flag state exclusive jurisdiction over incidents occurring on the high seas and the jurisdiction of the port state over matters occurring beyond the maritime zones considered part of the territory of that state. ${ }^{27}$

It has been noted already that "the principles of extraterritorial jurisdiction would (...) seem to leave room for port States to apply requirements which relate to conduct beyond the territory of the individual port State, the extent of those requirements ultimately depending on the 'reasonable interest' of the port State in the matter concerned". ${ }^{28}$ In other words, it appears that nothing prevents a port state from giving extraterritorial application to its laws over ships in port, except a matter of reasonableness or comity. These two limits serve to prevent illegitimate interferences with flag state jurisdiction, either when it is exclusive or when allowing residual port state jurisdiction.

Indeed, the law of the sea regime relies on international cooperation and encourages refrain from undue interferences with the jurisdiction of other states. ${ }^{29}$ In this circumstance, unilateral extraterritoriality easily becomes synonymous of extra-jurisdictionality. ${ }^{30}$ This is so in the sense that extraterritoriality refers not only to legal prescriptions which consider extraterritorial conduct but also which consider conduct that occurred under a presumptive state of freedom, in particular from the reach of port state jurisdiction and precisely because this capacity is generally understood as only being a means of ensuring compliance with international standards.$^{31}$ In other words, prescriptions of law to be enforced at port with regard to conduct that occurred, totally or partially, under a third state's jurisdiction can contribute to disrupt the balance of jurisdiction agreed under both the UNCLOS framework and subsequent treaties. Unilateral extraterritoriality is then a matter of international law and not only of state domestic affairs.

24 The ILC report still refers mostly to the teachings of the 1927 Lotus case and reaffirms that the lawfulness of the exercise of extraterritorial jurisdiction is determined by international law. Vide the Case of the S.S. "Lotus" (France v. Turkey), Judgement No. 9 of 7 September 1927, P.C.I.J. Reports 1928, Series A. No. IO, at I8-19

${ }_{25}$ I. Brownlie, Principles of Public International Law (Cambridge University Press, Cambridge, 2008) at 318 arguing that "[ $t$ ]he view that a ship is a floating part of state territory has long fallen into disrepute".

26 UNCLOS, supra n. 8, at Article 9I (nationality of ships).

27 The assertion of flag state jurisdiction is said to be 'exclusive' over the high seas, but still encompasses some very few exceptions, namely visiting rights and hot pursuit. UNCLOS, supra n. 8, at Article iıo (right of visit) and Article iII (right of hot pursuit).

28 H. Ringbom, supra n. 17, at 366.

29 UNCLOS, supra n. 8, at Article 197 (cooperation on a global or regional basis) for the protection and preservation of the marine environment. Another example is the principle of due regard to the interests of third states, present inter alia in the preamble ("the desirability of establishing through this Convention, with due regard for the sovereignty of all States...").

30 J.H. Knox, 'A Presumption Against Extrajurisdictionality', I04 American Journal of International Law (2010) at 351.

${ }_{31}$ UNCLOS, supra n. 8, at Article 218 (port state enforcement) and the restriction to violations of "applicable international rules and standards established through the competent international organization or general diplomatic conference". 
But apart from polluting discharges "there is no suggestion in UNCLOS that port States may take enforcement action against violations which have occurred on the high seas or in other States' coastal waters" ${ }^{32}$ This means that the international legal basis port state extraterritoriality relies upon is outside of the jurisdictional rules set by that treaty. Can it be based on the general principles of extraterritorial jurisdiction? According to Ringbom, "the legal limits to the extraterritorial requirements are mainly to be sought in the limits to States' prescriptive jurisdiction over foreign ships" ${ }^{33}$ This means that enforcing non-internationally-sanctioned standards would be illegal in itself. Nonetheless, Schachter explains that "enforcement activity within a State requires that the law being enforced is internationally valid within the jurisdiction to prescribe" [emphasis added]. ${ }^{34}$ Therefore, the unilateral enforcement of a rule integrating some extraterritorial component, even over a foreign ship at port, will be lawful as long as its prescription is not unlawful under international law. ${ }^{35}$

Extraterritoriality from the port can be achieved through some legislative techniques that rely on the territoriality of the enforcement at port rather than on recourse to the principles of extraterritorial jurisdiction or on expansive interpretations of treaties. We are referring to ( $\mathrm{I}$ ) the reformulation of the offence, so as to bring the locus of the violation within the territorial jurisdiction of the port State, (2) the detachment of the offence from the extraterritorial conduct (the operational becoming continuous), e.g. falsification of oil record books, or (3) the territorialisation of the offense by focusing on the inport investigation of the violations. ${ }^{36}$ This way a state can justify port-based extraterritoriality on an extensive application of the territoriality principle rather than necessarily on its exceptions, i.e. on the principles of extraterritorial jurisdiction.

As Ringbom adds, those three legal techniques are limited by the restraint that is due in principle and also by the rule of proportionality between the objectives to be achieved and the measures to be taken to achieve them. ${ }^{37}$ This signifies that extraterritoriality can be achieved through indirect means that do not make use of the international principles of extraterritorial jurisdiction but rather that rely on extensive interpretations on the territorial principle. Knowing whether the effects that result from concrete territoriality principle-based assertions fit the category of extraterritorial jurisdiction then becomes the object of legal debate.

\section{EU'S PORT STATE EXTRATERRITORIALITY OVERSHIP-SOURCE POLLUTION}

In the second part of this paper we analyse how unilateral extraterritoriality actually plays out in the practice of the EU by looking at practical examples that illustrate how it reveals itself in assertions of jurisdiction at port. We firstly give a brief overview on the EU's environmental extraterritorial action (I) and secondly, by focusing on the two above-mentioned cases where the EU unilaterally made use

\footnotetext{
32 H. Ringbom, supra n. 17, at 356

33 H. Ringbom, supra n. 17, at 356.

34 O. Schachter, International Law in Theory and Practice (Martinus Nijhoff, 199I) at 257.

35 Against this idea: E. Papastavridis, The Interception of Vessels on the High Seas: Contemporary Challenges to the Legal Order of the Oceans (Bloomsbury Publishing, London, 2014).

36 These techniques have been named by H. Ringbom, supra n. 17.

37 H. Ringbom, supra n. 17, at 369.
} 
of port state capacity to enhance the protection and preservation of the marine environment, we explain what legislative mechanisms were actually used to achieve those objectives and what international legal questions they raise (2).

\section{(I) The EU's environmental extraterritoriality}

The European Union is not a state under international law. Its competence to prescribe legal norms is not original but derived from the legislative powers that its member states attribute to it. This attribution of powers is done by the means of international treaties such as the 2007 Treaty of Lisbon, composed by both the Treaty on European Union [hereinafter TEU] and the Treaty on the Functioning of the European Union [hereinafter TFEU].38

When states, through those treaties, attribute competence to the EU, such an attribution is limited to the jurisdiction its member states originally possessed under international law. The member states are, under international law, the sole entities originally entitled to assume the burden of prescribing and enforcing binding laws. They are hence consenting parts of a collective and overarching policy strategy that makes use of their jurisdictional entitlements to have an impact on the development of international law. ${ }^{39}$

The EU's ambitions as a global actor are well acknowledged. $4^{\circ}$ In particular, environmental concerns are present among the Union's aims and objectives. ${ }^{4 \mathrm{I}}$ The EU is committed in helping to "develop international measures to preserve and improve the quality of the environment and the sustainable management of global natural resources, in order to ensure sustainable development". ${ }^{42}$ Achieving this objective requires concrete prescriptions and the legal bases for EU environmental policy, found in TFEU Article 19I, do not appear to prevent the EU from incorporating in them extraterritorial conduct.43

${ }_{38}$ Treaty of Lisbon amending the Treaty on European Union and the Treaty establishing the European Community [2007] OJ C306/or.

39 "The Union is directed to pursue its general external objectives when developing and implementing the external dimension of its internal policies", in M. Cremona, 'EU External Relations: Unity and Conferral of Powers' in L. Azoulai (ed.) The Question of Competence in the European Union (Oxford University Press, Oxford, 2014), at 85.

${ }_{40}$ "[T]he EU has increasingly sought to assert itself as a prominent player in global environmental governance, by gradually developing an environmental policy with a marked external dimension and by being proactively engaged in the shaping and application of international environmental law" in G.M. Durán \& E. Morgera, Environmental Integration in the EU's External Relations: Beyond Multilateral Dimensions (Bloomsbury Publishing, London, 2012) at 5-6.

${ }_{4 r}$ They are first referred to in the ninth recital in the preamble to the Treaty of Lisbon, which is, according to P.J. Kuijper, et al. The Law of EU External Relations: Cases, Materials, and Commentary on the EU (Oxford University Press, Oxford, 2013), at 807, "intended to reassure EU citizens that economic integration within the Union must not come at the cost of other societal goals, notably those of social progress, sustainable development and environmental protection". Art. 3(3) of the Treaty on European Union further confirms this by adding that "It shall work for (...) a high level of protection and improvement of the quality of the environment"

${ }_{42}$ TEU, supra n. 38 , Art $2 \mathrm{I}(2)(\mathrm{f})$ : "help develop international measures to preserve and improve the quality of the environment and the sustainable management of global natural resources, in order to ensure sustainable development".

43 J.H. Jans and H.H.B. Vedder, European Environmental Law: After Lisbon (Europa Law Publishing, Groningen, 2012), at 38. C. Eckes, 'EU climate change policy: can the Union be just (and) green?' in D. Kochenov \& F. Amtenbrin (eds) The European Union's Shaping of the International Legal Order (Cambridge University Press, Cambridge, 2014) at 194. 
We submit that 'promoting measures at the international level' can be interpreted broadly. Because international law also evolves through state practice that with time, consistency and acceptance becomes custom, it follows that some unilateral endeavour, a single legal prescription, can be the start of a recognized practice that generates binding effects if not objected and if followed by most members of the international community. ${ }^{44}$ Apart from efforts at the diplomatic level to promote good practices, a way to 'promote measures' is then simply to apply them unilaterally, affecting foreign actors with that action..$^{45}$ In this sense, extraterritoriality is here understood as a means not only to enforce international standards but also for the EU to promote its environmental objectives and values globally. ${ }^{46}$ But recourse to extraterritoriality is only one of the available ways for states to take unilateral measures. It is a last resort option when compared to other means such as, for example, diplomatic pressure, economic sanctions or embargos..$^{47}$ That may explain why states have been so coy in using it when compared to other means available.

Whilst it is not the purpose of this paper to delve in the legal basis of port state jurisdiction in EU treaties, we note that these treaties themselves do not preclude the possibility for member states to give extraterritorial application to their environmental shipping standards. ${ }^{4}$ With the wording of TFEU Article 19I, EU member states actually seem to accept the possibility of taking recourse to extraterritoriality.

(2) The EU's unilateral extraterritoriality via port state jurisdiction

What follows is an overview of two of EU's unilateral initiatives that make use of port state jurisdiction (a) and an assessment on their lawfulness under public international law (b).

\section{(a) Analysing two examples of EU's reliance on port state jurisdiction}

We shall now give attention to two cases where port state jurisdiction has been used as a means to give extraterritorial application to EU environmental standards: the double hull regulation (i) and the system for monitoring, reporting and verifying shipping $\mathrm{CO}_{2}$ emissions (ii).

44 K. Wolfke, 'Some Persistent Controversies Regarding Customary International Law', 24 Netherlands Yearbook of International Law (1993), at 7, explaining that " $\mathrm{t}]$ he formulation of customary rules may be undertaken by anyone at any time".

45 The EU does not appear to have developed something akin to a 'presumption against extraterritoriality' as it is the case, for example, in the United States of America. W.S. Dodge, 'Understanding the Presumption Against Extraterritoriality', 16 Berkeley Journal of International Law (1998), at 85.

46 H. Ascensio, Étude: l'extraterritorialitécomme instrument (2010), electronically available at <http://www.diplomatie.gouv.fr/fr/IMG/pdf/I_2PESP_2_Etude_lextraterritorialite_comme_instrumentx_cle84485e.pdf>, accessed I2 November 2015.

47 R. Mohamad, 'Unilateral Sanctions in International Law: A Quest for Legality' in A.Z. Marossi, \& M.R. Bassett (eds.) Economic Sanctions under International Law: Unilateralism, Multilateralism, Legitimacy, and Consequences (Springer, Heidelberg, 2015) at 71 .

${ }^{48}$ On the legal basis for EU external competence over maritime transport, see L. Nengye\& F. Maes, 'The European Union and the International Maritime Organization: EU's External Influence on the Prevention of Vessel-Source Pollution', 4I Journal of Maritime Law e $\mathcal{O}$ Commerce (2010), at 583. 
(i) The first case is taken from what has been baptized as 'the Erika packages'. ${ }^{49}$ These packages referred to various issues concerning both the environment and 'safety of navigation'. ${ }^{\circ}$ Many elements of the package fit the objective of 'marine environmental protection' as referred to in UNCLOS, Part XII; the particular case that we study here is the so-called double hull regulation. ${ }^{\text {.I }}$

The reliance on port state jurisdiction in the Erika packages is well illustrated by the overhaul of the port state control directive..$^{2}$ All EU ports are bound not only to the 1982 Paris MOU but also to this directive which imposes mandatory inspection targets to all member states, hence enhancing the enforcement of international standards and, of course, of EU law. ${ }^{53}$

The EU's decision to accelerate the phasing-in of the double hull requirement over all foreignships visiting its member state's ports was taken unilaterally in the sense that the IMO already had

49 Pressure of the public opinion following the 1999 Erika oil tanker spill prompted the European Commission to propose action at Community level. According to the Commission, this action was "designed to bring about a change in the prevailing mentality in the seaborne oil trade" and because "the net should be tightened on those who strive for short term personal financial gain at the expenses of safety and the marine environment" [emphasis added], in Communication from the Commission to the European Parliament and the Council on the safety of the seaborne oil trade $[\operatorname{COM}(2000) 142$ final - Not published in the Official Journal].

so The packages of these measures became known as Erika I, Erika II and Erika III. The first Erika package (Erika I) contained three sorts of measures. Those measures concerned classification societies (Directive 2001/ro5/EC amending Directive 94/57), port state control (Directive 2001/105/EC amending Directive 94/57) and double hull oil tankers (Directive 200I/I06/EC amending Directive 95/2I). The second Erika package (Erika II) contained other three sorts of measures. Those measures concerned the monitoring, control and information system for maritime traffic (Directive 2002/59/EC of 27 June 2002), the setting of a Maritime Safety Agency (Regulation I406/2002 of 27 June 2002) and the creation of a fund to compensate victims of oil pollution (Proposal 2000/0326(COD), approved by Parliament and Council on 5 November 2002). Finally, the third Erika package (Erika III) was announced in early 2004 but only adopted after the entry into force of the Treaty of Lisbon (more precisely on II March 2009). The package includes two Regulations and six Directives, transposed between November 2010 and January 2012, on quality of flags (Directive 2009/2I/EC of the European Parliament and of the Council of 23 April 2009 on compliance with flag State requirements), classification societies (Regulation (EC) No 391/2009 of the European Parliament and of the Council of 23 April 2009 on common rules and standards for ship inspection and survey organisations and Directive 2009/15/EC of the European Parliament and of the Council of 23 April 2009 on common rules and standards for ship inspection and survey organisations and for the relevant activities of maritime administrations summary), port state control (Directive 2009/16/EC of the European Parliament and of the Council of 23 April 2009 on port State control), traffic monitoring (Directive 2009/17/EC of the European Parliament and of the Council of 23 April 2009 amending Directive 2002/59/EC establishing a Community vessel traffic monitoring and information system), accident investigation (Directive 2009/I8/EC of the European Parliament and of the Council of 23 April 2009 establishing the fundamental principles governing the investigation of accidents in the maritime transport sector and amending Council Directive 1999/35/EC and Directive 2002/59/EC of the European Parliament and of the Council), liability of carriers (Athens convention) (Regulation (EC) No 392/2009 of the European Parliament and of the Council of 23 April 2009 on the liability of carriers of passengers by sea in the event of accidents), and insurance (Directive 2009/20/EC of the European Parliament and of the Council of 23 April 2009 on the insurance of ship owners for maritime claims).

${ }_{51}$ The drafting of Erika III package resulted from the pressure caused by a subsequent environmental disaster, the sinking of the Prestige in 2002, and in particular from unilateral action taken by Spain as a response to it. See Law Decree 9/2002, I3 December 2002, (BOE no. 299, I4 December 2002) and IMO Doc. MEPC/Circ. 402, I5 January 2003. See also V. Frank, 'Consequences of the Prestige Sinking for European and International Law', 20 The International Journal of Marine and Coastal Law (2005).

52 E.J. Molenaar \& B. Pons, 'The EC Directive on Port State Control in Context', II The International Journal of Marine and Coastal Law (1996),pp. 24I-288

53 J. van Leeuwen \& K. Kern, 'The External Dimension of European Union Marine Governance: Institutional Interplay between the EU and the International Maritime Organization', I3 Global Environmental Politics (2013), at 75. 
established its own calendar. ${ }^{54}$ The EU did not only sought to promote safety of navigation, for every accident at sea that can hamper normal navigation, but also ended up promoting a higher threshold of environmental protection by discouraging, through a preventive mechanism, fragile and leakage-prone ships from coming to European ports and navigating through European coastal waters. 55

The extraterritoriality of the measure reveals itself in the following terms:

"[a]n oil tanker shall not be allowed to enter into ports or offshore terminals under the jurisdiction of a Member State beyond the anniversary of the date of delivery of the ship (...) unless it complies with the Condition Assessment Scheme referred to in Article 6"..$^{6}$

This port entry condition has an impact on the construction of ships abroad, as well as in shipping contracts involving European journeys. ${ }^{57}$ Although "the purpose of this EU regulation is therefore to reduce the risk of accidental oil pollution in European waters by speeding up the phasing-in of double hulls" (emphasis added) it still does applies "to all tankers of 5000 tonnes deadweight or above, which enter or leave a port or offshore terminal or anchor in an area under the jurisdiction of an EU country, irrespective of their flag, or which fly the flag of an EU country" (emphasis added). ${ }^{8}$ By preventing such foreign ships from entering its ports, the EU prescribed a standard that interferes with flag state jurisdiction, for ships would have to fit this port state requirement prior to starting their journey. 59

But the most interesting aspect in this case is that the offence in itself - navigating with a single hull- was not framed as an irregular journey. Instead, a restriction of access to port was set on the basis of the territorial sovereignty of a state over its internal waters. This was a means to unilaterally achieve a degree of extraterritoriality without relying on the principles of extraterritorial jurisdiction as a legal basis for it. Such EU reliance on the territorial nexus of port state jurisdiction constitutes a legal drafting technique that provides a less controversial legal basis to the extraterritorial application of EU law.

54 Following the 1989 Exxon Valdez oil spill, the USA enacted the Oil Pollution Act of 1990 (33 U.S.C. 270I-276I) banning single hull ships from USA waters, an unilateral move that prompted the IMO to act in this respect. P. Ehlers \& R. Lagoni, International maritime organisations and their contribution towards a sustainable marine development (LIT Verlag, Münster, 2006), at 93.

s5 A. Proelss, 'The 'Erika III' Package: Progress or Breach of International Law?' in H.J. Koch et al. (eds) Climate Change and Environmental Hazards Related to Shipping: An International Legal Framework (Martinus Nijhoff, Leiden, 20I2), at I5I, explaining that the duty to notify, that results from the EU directive on port state control, "does not represent an exercise of extraterritorial jurisdiction”.

56 Which was defined as the Condition Assessment Scheme adopted by MEPC Resolution 94(46) of 27 April 2001. Regulation (EC) No 417/2002 supra n 3, at Article 5.

57 UNCLOS, supra n. 8, at Article 2I(2) (laws and regulations of the coastal state relating to innocent passage) on the primary rule governing the design, construction, manning and equipment of foreign ships.

58 Regulation (EC) No 417/2002, summary, supra n. 3.

59 E.J. Molenaar, Coastal state jurisdiction over vessel-source pollution (Kluwer Law International, Den Haag, I998) at 94, explaining that "[a] vessel's conformity with CDEM standards remains generally the same throughout its voyage and deficiencies only become apparent during the ship's stay in port. Examples are the ship's (non-)compliance with double hull requirements or adequately qualified crew. The question is then whether the geographical reference in Article 220(I) has the specific purpose of excluding certain standards from enforcement under this provision, such as CDEM standards" referring to Hakapää's position that CDEM standards "follow the ship as it enters the port" and are therefore not extra-territorial in nature, and his conclusion that CDEM standards should be left to coastal state jurisdiction because extra-territoriality is the essence of port state enforcement jurisdiction in n. IO4. 
The effectiveness of this unilateral measure is well illustrated from subsequent negotiations on the matter..$^{60}$ Although there was an initial suspicion to this particular initiative at the multilateral level, it actually led to a rescheduling of the IMO calendar. ${ }^{6}$ This unilateral application of EU standards over foreign ships, by affecting the construction requirement of tankers, indirectly served the purpose of the EU to promote a preventive approach to pollution accidents. It hence protected both its member states' coastal waters and, we submit, the marine environment as a whole, acting in the interest of the international community.

(ii) The second case is about the inclusion of the shipping industry in the EU emission's trading scheme. ${ }^{62}$ A European Commission proposal was adopted on 29 April 2015 that seeks to establish a EU system for monitoring, reporting and verifying (MRV) emissions from large ships using EU ports. ${ }^{63}$ The motivations for this measure fit EU's environmental objectives. It relates to the protection of the environment, being framed as a measure aimed at mitigating climate change. The EU will have access to shipping emissions information and it will create a database with that.

This Regulation brings back to our attention the recent EU attempt to include aviation in the greenhouse gas emissions allowance trading scheme, which resulted in the ATAA Case at the European Court of Justice [hereinafter, ECJ]. ${ }^{64}$ It could well be argued that the case we now introduce consists on a continuation or even a development of a broader European strategy towards valueoriented external action. This new initiative includes some degree of port state extraterritoriality which reveals itself in the following terms:

"[a]11 intra-Union voyages, all incoming voyages from the last non-Union port to the first Union port of call and all outgoing voyages from a Union port to the next non-Union port of call, including ballast voyages, should be considered relevant for the purposes of monitoring". ${ }^{65}$

This EU initiative is undeniably outward looking in the sense that it considers 'conduct' that occurred beyond European waters: i.e., extraterritorial conduct. ${ }^{66}$ The legal consequences for now, will

60 The original IMO calendar was adopted in 1992. Following the Erika incident and the EU's unilateral measure, the IMO adopted a revised phase-out schedule for single hull tankers, which entered into force on I September 2003 (known as the 200 I amendments to MARPOL). The revised requirements set out a stricter timetable for the phasing-out of single-hull tankers. In December 2003, further revisions to the requirements were made, accelerating further the phase-out schedule. Text available at <http://www.imo.org/en/OurWork/Environment/PollutionPrevention/OilPollution/Pages/ constructionrequirements.aspx>, accessed I8 September 2015.

${ }_{61}$ A. K-J. Tan, Vessel-Source Marine Pollution (Cambridge University Press, Cambridge, 2006) at 147.

${ }_{62}$ M. Kremlis, 'The Inclusion of the Shipping Industry in the EU ETS', I9 European Energy and Environmental Law (2010), $145-156$.

63 Regulation (EU) 2015/757, supra n. 4. See also Regulation (EU) 525/20130n a mechanism for monitoring and reporting greenhouse gas emissions and for reporting other information at national and Union level relevant to climate change and repealing Decision No 280/2004/EC.

${ }_{64}$ C-366/IO, Air Transport Association of America $v$ Secretary of State for Energy and Climate Change. This judgment upheld the validity of Directive 2008/10I/EC of 19 November 2008 which amended Directive 2003/87/EC so as to include aviation activities in the scheme for greenhouse gas emission allowance trading within the Community.

${ }_{65}$ Regulation (EU) 2015/757, supra n.4, at (14).

66 In the $\operatorname{COM}(2013 / 479)$, Communication From The Commission To The European Parliament, The Council, The European Economic And Social Committee And The Committee Of The Regions from 28 June 20I3, the European Commission discussed its plan to start with an MRV and then move to a definition of emission reduction targets, and then finally to 
entail expulsion from the port of that member state. ${ }^{67}$ If, in the future, the EU happens to detach an offence of irregular $\mathrm{CO}_{2}$ emissions from the extraterritorial conduct itself by sanctioning false declarations, it would be following a legislative technique the USA has previously experimented in 1990. ${ }^{68}$ This wouldn't be completely innovative from the standpoint of international law as it would still rely on a territorial component of the offense: the presence of the ship in the port.

The IMO has also been making efforts with regard to air pollution caused by ships. ${ }^{69} \mathrm{But}$ UNCLOS also explicitly allow for unilateralism on this matter, hence providing a legal basis to this EU initiative, the unilateral factor being, in this case, the reliance on port state enforcement. ${ }^{70} \mathrm{It}$ comes therefore with no surprise that the EU Parliament itself, when referring to this initiative, already admitted the norm-setting potential of unilateralism, in the same vein it had proceeded with the Erika packages years before. ${ }^{71}$

These two cases demonstrate that port state jurisdiction can be used as a trigger to apply EU law to extraterritorial conduct, an attempt that has occurred more recently in other fields of regulation and that has already been termed as the 'territorial extension' of EU law. ${ }^{72}$ In analysing both these cases we referred to the unilateral nature of the jurisdictional prescriptions over foreign-flagged ships at port that 'capture' extraterritorial conduct. That unilateralism does nonetheless raise some questions of international legality.

introduce market based measures available at

<http://ec.europa.eu/clima/policies/transport/shipping/docs/com_20I3_479_en.pdf>, p.5, accessed I7 September 2015.

${ }_{67}$ Regulation (EU) 2015/757, supra n. 4, at (32): "[i]n the case of ships that have failed to comply with the monitoring and reporting requirements for two or more consecutive reporting periods and where other enforcement measures have failed to ensure compliance, the competent authority of the member state of the port of entry may issue an expulsion".

${ }_{68}$ See supra n. 54. See also Title I8 of the United States Code, section IooI, the 'False Statements Act' and the case US v. Royal Caribbean Cruises, Ltd., II F. Supp. 2 d 1358 (S.D. Fla. 1998), where the US coast-guard sanctioned a case of extraterritorial pollution by framing it as false declarations in the log book inspected within port.

69 UNCLOS, supra n. 8, at Article 212(3) affirming that "States, acting especially through competent international organizations or diplomatic conference, shall endeavour to establish global and regional rules, standards and recommended practices and procedures to prevent, reduce and control such pollution". Under this framework, a new annex (VI) to the International Convention for the Prevention of Pollution from Ships (MARPOL) was added in 1997 with regulations which seek to minimize airborne emissions from ships (SOx, NOx, ODS, VOC shipboard incineration). This annex entered into force on 19 May 2005 and was subsequently upgraded.

70 UNCLOS, supra n. 8, at Article 212(2) affirming that "States shall take other measures as may be necessary to prevent, reduce and control such pollution" and also Article 222 (enforcement with respect to pollution from or through the atmosphere). The Virginia Commentary explains that "As in the case of article 212, article 222 does not address the problem of pollution of or through the atmosphere which does not cause pollution of the marine environment", in M.H. Nordquist (ed) United Nations Convention on the Law of the Sea, 1982: A Commentary, Volume IV (Martinus Nijhoff, Dordrecht, 1993), at 319 .

$\pi$ The European Parliament explicitly referred to this legislation as "an opportunity to influence negotiations within the International Maritime Organisation" available at <http://www.europarl.europa.eu/news/en/news$\mathrm{room} /$ content $/ 20150424 \mathrm{IPR} 45728 / \mathrm{html} /$ Ships\% E2\%80\%99-CO2-emissions-MEPs-approve-new-reporting-rules $>$ accessed ${ }_{17}$ September 2015 .

72 J. Scott, 'Extraterritoriality and Territorial Extension in EU Law', 62 American Journal of Comparative Law (2014), at 3, where she affirms that "a measure will be regarded as giving rise to territorial extension, when its application depends upon the existence of a relevant territorial connection but where the relevant regulatory determination will be shaped as a matter of law, by conduct or circumstances abroad". 


\section{(b) Remarks on the international legality of EU practice}

In both the Erika packages and in the MRV system, the EU responds to internal imperatives to explore the jurisdiction opportunities the law of the sea regime provides. Jurisdiction over ships at port provokes a clash between the broad scope of the territoriality principle and particular norms in treaty law, namely UNCLOS rules of jurisdiction. This allow for some legal innovation. By this we mean that the law of the sea regime, whilst adapting the principles of jurisdiction for the purpose of regulating the ocean space and human activities therein, has not completely closed the realm of possibilities. This is so namely because science and technology are in constant evolution and might alter the perspective we have on the ocean space. ${ }^{73}$ It is so also because the function of the sovereignty principle in international law is challenged by globalization trends.

The two cases studied in this paper show that the EU hesitates in making use of its port state jurisdiction without emphasizing the territoriality of the enforcement. It rather makes use of complex legislative techniques even when aiming to tackle extraterritorial conduct. These techniques demonstrate that the EU still relies on the fact that the ship is voluntarily present in its ports rather than just using an extensive interpretation of the universality principle, for example. The lack of certainty on whether prescriptive jurisdiction opportunities offered under the law of the sea regime represent or not an exhaustive set of rules does reveal some margin of manoeuvre and the EU is seeking to make use of it to achieve its environmental objectives.

The discussion on the international legality of the two cases mentioned above is posited on whether the EU member states can apply EU standards on all ships, especially regarding environment-threatening conduct occurring on the high seas where flag states retain exclusive jurisdiction. ${ }^{74}$ We have noted that port state territorialisation of offences remains a privileged means of achieving some degree of extraterritoriality without actually claiming any exception to the more consensual territorial basis of jurisdiction. But nothing would seem to prevent unilateral extraterritoriality from the port. First, because the international community as a whole benefits from these measures as every single pollution incident has a destructive effect to the oceans' ecosystems - a perspective that assumes that biology respects no legal delimitation lines of jurisdiction and that any act of pollution is, ultimately, a common concern to all..$^{55}$ And second, because relying too much on the territorial component of port state jurisdiction to capture extraterritorial conduct can actually cause it to empty the meaning of territoriality in international law. ${ }^{76}$

EU's recourse to port state jurisdiction indicates that unilateral assertions of extraterritorial jurisdiction are not per se unlawful but rather a last resort means of participating in the development of international law. We have found no duty to refrain from resorting to extraterritoriality at port.

73 P.E. Steinberg, The Social Construction Of The Ocean (Cambridge University Press, Cambridge, 200I).

74 UNCLOS, supra n. 8, at Article 92(I) affirming that "Ships shall sail under the flag of one State only and, save in exceptional cases expressly provided for in international treaties or in this Convention, shall be subject to its exclusive jurisdiction on the high seas (...)".

75 N. Krisch, 'The Decay Of Consent: International Law In An Age Of Global Public Goods', ro8 American Journal of International Law (2014), pp.I-40

${ }^{6}$ C. Ryngaert, 'Whither Territoriality? The European Union's Use of Territoriality to Set Norms with Universal Effects' in C. Ryngaert et al. (eds), What's Wrong with International Law(MartinusNijhoff, Leiden, 20I5), pp.434-448. 


\section{CONCLUSION}

Not so long ago we could read that "unless the requirements are based on 'alternative techniques' for establishing jurisdiction (...) the port State is likely to face difficulties in establishing prescriptive jurisdiction for the measure, in the absence of a link to its own interests" (emphasis added)..$^{77}$ By questioning the perception that environmental interests are linked to the interests of one state, we sought to demonstrate that EU's extraterritoriality is aimed at developing the legal protection to the marine environment as a whole. To achieve this objective, the EU has been exploring opportunities offered by its member states' port state jurisdiction to apply its more stringent standards over foreign ships. However, we have noticed that EU prescriptions avoid engaging with the principles of extraterritorial jurisdiction to justify these assertions. They rather twist the scope of territoriality under international law, relying on the presence of vessels at port to ascertain shipping standards. This twisting highlights the insufficiency of the jurisdiction principles to tackle global issues such as marine environmental governance.

It is impossible to say whether this EU eco-friendly unilateralism will disrupt the preponderance that multilateral for a rightfully retain (such as the IMO by attribution under UNCLOS) ${ }^{78}$ Normative fragmentation is a possible consequence of a generalized recourse to unilateral extraterritoriality. This consequence stems negative effects over international law's role in global governance, such as lack of legal certainty and predictability. So in the particular case of extraterritoriality through port state jurisdiction, we would suggest that unilateralism should remain, as it has been, limited to matters which are in the interest of the international community such as the protection and preservation of the marine environment from accidental, operational or intentional incidents of ship-source pollution. ${ }^{79}$

77 H. Ringbom, supra n. 17, at 370.

78 M. Hakimi, 'Unfriendly Unilateralism', 55 Harvard International Law Journal (2013), pp.105-I50 See the statement from IMO Secretary-General Koji Sekimizu ahead of COP2I talks, 'Shipping and climate change' available at <http://www.imo.org/en/MediaCentre/HotTopics/GHG/Documents/Shipping\%2oand\%2oclimate\%2ochange.pdf>, accessed 16 November 2015 .

79 Y. Tanaka, 'Protection Of Community Interests In International Law: The Case Of The Law Of The Sea', I5 Max Planck Yearbook of United Nations Law (2011), pp.329-375. 